\title{
An Approach to Marketing Implementation with the Perspective of Wu Hsing
}

\author{
Guoqing Zhang \\ Human Resources Dept \\ Yunnan Vocational College of Finance and Economics \\ Kunming, Chin \\ 554826674@qq.com
}

\begin{abstract}
Wu Hsing, five elements (metal, wood, water, fire and earth), was held by the ancients to compose the physical universe and later used in traditional Chinese medicine to explain various marketing implementation. Marketing refers to the sum of activities involved in directing the flow of goods and service from producers to consumers. Marketing's principal function is to promote and facilitate exchanges. The originality lies in a attempt to answer 1) what kind of connection between the eastern $\mathrm{Wu}$ Hsing theory and the western marketing business theory there could be when they are two totally different realms, and 2) what similarities there could be between the five elements and the organizational management of marketing, by which the solutions to existing problems in marketing implementation with the perspective of $\mathrm{Wu}$ Hsing are presented. The significance of the attempt lies in an assumption that if the ancient wisdom endows us a new perspective to implement modern business strategies. The more the assumption being verified, culturally the brighter the ancient wisdom's light shed on human culture, and technically the more efficient the marketing implementation is.
\end{abstract}

Keywords—Wu Hsing, marketing strategy

\section{INTRODUCTION}

$\mathrm{Wu}$ Hsing, five elements (metal, wood, water, fire and earth), was held by the ancients to compose the physical universe and later used in traditional Chinese medicine to explain various. The five elements are: Water, Fire, Wood, Metal and Earth. These elements were believed to overcome and succeed one another in an immutable cycle and were correlated with the cardinal directions, seasons, colors, musical tones, and bodily organs. Wood feeds Fire; Fire creates Earth (ash); Earth bears Metal; Metal enriches Water (as in water with minerals is more beneficial to the body than pure water) Water nourishes Wood. Wood parts Earth (such as roots; or, Trees can prevent soil erosion); Earth dams (or muddles or absorbs) Water; Water extinguishes Fire; Fire melts Metal and Metal chops Wood. Wu Hsing cycle served as a broad explanatory principle in Chinese history, philosophy.

Marketing refers to a series of activities promoting and facilitating exchanges. By exchanging products and services with others, either individuals or groups satisfy their needs and wants. Marketing does not confine itself to any particular category of economy, since products have to be exchanged and marketed within all kind of contexts. Functionally speaking, marketing is not merely characterized by profitmaking; For instance, such organizations as health care and education can not alienated themselves from marketing.

The first question arises that what kind of connection between the eastern $\mathrm{Wu}$ Hsing theory and the western marketing business theory there could be when they are two totally different realms. Marketing, rather than confined to a business behavior, is a dynamic process of organizational behavior and comprehensively speaking, a philosophy.

The second question has to be discussed that what similarities there could be between the five elements and the organizational management of marketing. The organizational management of marketing can be categorized into five components: environment; input; throughput; output; feedback. Wu Hsing (five elements) is usually used to describe the state in nature: Wood is linked with a sense of growth, which generates abundant wood and vitality marketing, Fire a swelling, flowering, brimming with fire and energy, Earth leveling and dampening (moderation) and fruition, Metal harvesting and collecting and Water retreat, in which stillness and storage pervades. Correspondingly, environment (adaptability and atmosphere) referring to growth is equal to Earth highlighting leveling and dampening; input (the philosophy of organization) is identical to fire characterized with flowering, brimming and energy; throughput (implementation) is same as Wood; output (product or outcome) is like Metal featuring harvesting and collecting; feedback (evaluation from outside and examination from inner.) the interaction is illustrated below

\section{LITERATURE REVIEW}

With the increased interests in the role of intermediary and functions economic science attach more importance to market research, better product design, effective distribution, and sustained communication with consumers in the success of their brands. Marketing concepts are concerned with not only goods and services but also ideologies, location, personalities, news, and public relations [1].

However, most present attempts are developed with the economy context. Few scholar notices or even wonders if the common sense of marketing has any relevance to any ancient 
established theories. This thesis aims to answer the questions that if the eastern $\mathrm{Wu}$ Hsing theory works on the western marketing business theory; if so, how; what significance $\mathrm{Wu}$ Hsing theory will bring to the theory and practice of the marketing theory.

\section{THE EMBODIMENTS OF WU HSING PRINCIPLES IN THE MARKETING ORGANIZATION}

Similar to $\mathrm{Wu}$ Hsing Principles, the marketing organization consists of five elements as well: environment, input, throughput, output and feedback. It will be unfolded that how $\mathrm{Wu}$ Hsing is embodied in the marketing process.

\section{A. The Earth and environment of marketing}

Earth is leveling and dampening (moderation) and fruition, which is like the environment substantiating and thus nourishing the marketing. So the main approach is to form a positive environment by establishing an organic frame. The basic aim of marketing is to satisfy needs profitably. Companies must therefore first identify 3 factors: who needs? Who can satisfy them? How? For example, the personal transportation market consists of people who put different values on an automobile's cost, speed, safety, status, and styling.[2] For instance, no single dress can satisfy all ladies' needs. Furthermore, some ladies may wish to meet their needs of tastes with private tailors other than from shelves of supermarkets. Because of such variables, company must identify the different preference groups, or segments, of customers and decide which group(s) they can target profitably.

Secondly, more and more organizations attempt to adapt their offer and communication to each individual customer. By constructing an access to the information of individual customer characteristics and purchase records, the advent of database marketing provides more possibilities to serve customers [3].

Thirdly, a key step in marketing strategy, known as positioning, involves creating and communicating a message that clearly establishes the company or brand in relation to competitors [4]. Some products may be positioned as "excellent" with two or more features. However, claiming superiority along several dimensions seems too perfect to convince customers, hurting a company's trustworthiness. Furthermore, although the company qualifies itself as a particular position, the access to their public image is available, which provides customers with different images of the company [5]. This is how a positive environment formed with the consideration of the Earth's connotation: leveling and dampening (moderation) and fruition.

However, dialectically speaking, creating a favorable environment for your plants' growth must be preconditioned by a knowledge that what your plants indeed need and what if the environment used to be positive someday become a negative one. The question is saved to be answered later.

\section{B. The Fire and input of marketing}

Fire means an extending, flowering with fire and energy, which symbolizes a force or drive to facilitate something. Therefore, devices and methods must be highlighted now. Organizations use five devices to evaluate efficiency and monitor performance. The first is sales analysis, in which a comparison is made between sales goals and actual sales indicating both analysis of quantity and quantity. A second device is market-share analysis, in which a comparison is made between the sales of a company's and competitors. The typical indicators of market share are: comparisons between own sales and total market sales; own and competitors. Third, marketing cost of sales analysis, namely, how much sale goals will cost. The ratio of marketing cost of sales must be flexible and acceptable. Unlike cost analysis, financial analysis covers more estimation, such as expenses (along with others) from a corporate perspective. This includes a comparison of profits to sales (profit margin), sales to assets (asset turnover), profits to assets (return on assets), assets to worth (financial leverage), and, finally, profits to worth (return on net worth)[6]. Therefore, companies identify customers' response as an indicator of efficiency [7].

However, dialectically speaking, fire is a strong and inspirational drive but at same time a destructive force that burns things out. An inevitable question must be answered that how to keep fire serving as inspirational and forceful and at the same time to avoid its inflammability?

\section{The Wood and throughput of marketing}

Wood is linked with a sense of growth, which generates abundant wood and vital marketing. What is growth? Growth refers to the increases in cell size and number that take place during the life history of an organism. Growth is seldom random. Rather, it occurs according to a plan that eventually determines the size and shape of the individual. Having formed a positive environment and developed a strategy for marketing, a company must then decide which tactics will be most effective in achieving strategy goals and thus enable a growth. However, dialectically speaking, growth makes things bigger and better but the when growth is not properly regulated, anomalies and tumors may result. What if the growth become uncontrollable and turns out to be harmful to organism? The third question to be answered.

\section{The Metal and output of marketing}

Metal connotes harvesting and collecting. In other words, it implies collecting the products produced by former procedures and the consequences of previous actions or behavior. The contribution of marketing proves to be prominent when there has been a sharp comparison between high performance business and low one [9]. Organizations are able to know the efficiency of marketing performance by the achievements and outcome produced by former procedures and the consequences of previous actions or behavior, which is not necessarily mere profit-making, but public relations [10]. The social scholars often criticize marketers that some of their practices are too profit-oriented to be concerned or warned with social morals and thus deteriorate both spiritual well-being of both individual and groups involved in it. 
Without the denial of such circumstances, we are more likely tending to recognize the material wealth brought by marketing, which consequently substantiates the existence and prominence of spiritual reality. After all mater, the spiritual wealth must not be alienated from the prominence of physical one since virtues seldom shows up in a poverty haunted class [11]. Strategically speaking, poor and shallow marketing are deteriorating, but good ones are nourishing.

Although we labored for a good goal and have a great expectation for a harvest, there might be some immature or over-mature fruits which are worthless and even make a loss of our business. Therefore, the negative influence calls for an attention despite of marketing's contributions. A problem still remains unsolved that if it is possible for marketing turns negative influences into positive ones?

\section{E. The Water and feedback of marketing}

Unlike the four mentioned elements, Water, instead of being forceful, constructive and pushing, carries an implication on retreating, in which stillness and storage pervades. Feedback bears twofold meaning: 1) the return of part of the output of a machine, system, or circuit to the input in a way that affects its performance; 2) responses to something, intended to provide useful information for future decisions and development. In other words, feedback from society and peer business plays important role to guide future performance. What marketing can do to social welfare when it shows its efficiency in business? Despite of the criticism against resource crisis and environment pollution it leads to, most organizations are commendably meeting individual consumer demands as well as acting in the long-term interests of the consumer and society [12]. These dual objectives of many of today's companies have led to a broadening of the marketing concept to become the public marketing concept 13]. Generating customer satisfaction at the same time attending to consumer and public well-being in the long run are the core concepts of public marketing.

Although it proves that marketing have many other positive benefits such as accelerating economic development and creating new jobs for individuals and society, a question still remain unavoidable: is it possible for implementation of marketing to insist virtuous attempts when it is in nature a way of making profit. This is the last question to be answered.

\section{The SOlutions to the Questions AsKed BY Wu HSING PRINCIPLE}

Philosophically speaking, like a coin, everything has two sides: bright side and dark one. As the discussion about the bright sides has been finished, we have to face the dark ones. Before the elaboration, let's review the questions respectively left by the five elements and then present the solutions in terms of the basic idea of $\mathrm{Wu}$ Hsing: the five elements overcome and succeed one another in an immutable cycle.

\section{A. About Environment (Earth): what if the environment used to be positive someday becomes a negative one?}

Firstly, according to $\mathrm{Wu}$ Hsing theory, Fire creates Earth (ash). In other words, Fire is a helpful element to prosper
Earth. Taking it into the marketing theory, the maintenance of advantage of the environment depends on the input (the philosophy of organization and business strategy). In marketing strategy, four controls guarantee a healthy organization (environment) for marketing a business. They are profitability control, efficiency control, efficiency control and strategic control [14].

Profitability control and efficiency control serve as devices for a company closely monitoring its sales, profits, and expenditures. Profitability control demonstrates the relative profit-making potential of a company's different products and consumer groups. For example, 20\% of their products and customers contribute to $80 \%$ of their profits, which is called "Two: Eight Strategy" that helps a company to reallocate and redistribute their resources and effort [15].

Efficiency control are consisted of sales force, advertising, sales promotion, and distribution. For example, a company calculates sales calls a salesman makes each day, the time each call lasts, the cost of each call and thus to estimate its sales-force efficiency, by which the effectiveness of marketing efforts and cost-effectiveness of manner will be forecasted [16].

Strategic control processes enable executives to evaluate a company's marketing program from a critical perspective by specifically and objectively analyzing the efficiency of organization performance and strengths and maximizing its market opportunities. Marketing-effectiveness review and marketing strategy remarks are two devices for company to oversee the integration of its marketing tactics [17].

Besides, sales force and promotion, two facilitators of marketing, highlights their effectiveness and efficiency in carrying marketing functions. Furthermore, experience of broader expertise proves marketing contractors to be more effective when they are applied to broader external scope than in an internal department. In addition, they often are more driven to perform with high standards, since competition in market is usually aggressive, and poor performance could mean lost business [18].

Concisely, in order to avoid that the environment used to be positive turns out to be negative, a strong and strategic frame must be constructed. Specifically, a healthy input ensures a positive environment. Namely, Fire creates Earth.

\section{B. About input (Fire): how to keep fire serving as inspirational and forceful and at the same time to avoid its inflammability?}

According to $\mathrm{Wu}$ Hsing theory, Water extinguishes Fire. In other words, Water prevents fire from burning things out. Taking it into marketing theory, feedback prevents input from being deviated. Feedback from society and peer business plays important role to guide future performance. In practicing public strategies, marketers try to balance profits, consumer satisfaction, and public interest in their marketing policies. Many companies have achieved success in adopting public marketing. Two companies that were among the pioneers of public marketing are The Body Shop and Ben \& Jerry's Homemade Inc. Body Shop's products, highlighting 
its ingredients without chemicals and animal testing, are characterized by recycled package. Besides, the company claims that a percentage of profits each year is donated to charity organizations. Ben \& Jerry's donates a percentage of its profits to help to fight against poverty and pollution. The company initiates "caring capitalism," which involves the product as well as social and economic missions [19].

Concisely, a public impression and remark on a companies' social responsibility refrains the greediness in the nature of profit-making. For a better public relation and longrun profitability, companies tend to conform their strategy to the mainstream value and moral. To be precise, feedback guarantees the well-being of the input (strategy).

\section{About throughput (Wood): What if the growth become uncontrollable and turns out to be harmful to organism?}

According to $\mathrm{Wu}$ Hsing theory, Metal chops Wood. In other words, Scissors is a device to trim redundant or unnecessary parts of trees so as to keep tree growing in a health way. Taking it into marketing theory, Output (fruit and result) serves as a adjustor to throughput (implementation), which always is a warning of the well-being of throughput.

Tactical marketing involves creating a marketing mix of four components - product, price, place, promotion-that full fills the strategy for the targeted set of customer needs [20].

The first component is product, which refers to the offering made available to customers. Products can be categorized into two groups: physical products and intangible products. Physical products include everything that meets customers' needs and desired by a target market. It is important for a company to collect statistics in terms of physical products features and benefits. Traditionally, engineers are those who have the license to design products regarding to their own preferences and interests, waiting marketers invest and make products their invention. However, contemporary thinking calls for products to be designed based on customer input and not solely on engineers' ideas [21]. Before production of new product, the first one that the marketer communicates with is customer instead of the engineers.

The second component is price. Traditionally, price is determined by quality, cost of manufacture, and popularity in the market. However, modern society gives more factors grounding price. That is to say, price is determined by some new factors such as symbolic meaning, value of brand name and promotion strategy. For instance, a Mercedes-Benz's high price is determined by its high quality, which is contributed by multi-factors: manufactures, publicizing and the intangible quality sending symbolic meaning with prestige concern to customers. On the other hand, some companies makes such pricing strategies as more for the same and the same for less to win more mark share from their competitors. This kind of discount pricing has caused organizations in such industries as airlines and pharmaceuticals (which used to charge a price premium based on their past brand strength and reputation) to significantly reevaluate their marketing strategies [22].
The third component is distribution. When a product moves along its path from producer to consumer, it is said to be following a channel of distribution. For example, cow farm, wholesalers, and supermarkets are an integral channel of distribution for milk. This channel gives milk companies an easy access to the target market. In another example, venture capitals seek to put their investment in products which already practically convinced customers with their pragmatism. However, channel of distribution are too much confined within their established business. For instance, the channel of sea food cannot be used to distribute fruit. Therefore, marketers now are directly to customers through online commerce, skipping steps in the channel.

The fourth component is human resources. Human are the most effective and productive role in whole process and at the same time the most expensive means of promotion. However, their versatile creativity deserves it. Unlike other means, sales representative's promotion process is dynamic. Their articulation, logic reasoning, smiles and close communication personalize a complex marketing combined with dynamic advertisement promotion and changeable public relation strategy. They are good at selling complex products such the insurance and luxury products. And furthermore, the sales representative's performance proves to reduce company's advertising costs by personalizing company's own public position.

Advertising refers to all kind of forms and demonstration of promotion of products, services, or ideas. Print, broadcast and the Internet serve as major forms of advertising [23].Advertising functions as an inception of products while sales promotion an incentive to purchase. Advertising appears in a persuasion and sales promotions a motivation. Advertising is responsible for freshening those who do not know the product and promotion invites those who are not loyal to a specific brand and are concerned with low price and good value. In markets where brands share similarity, sales promotions is able to increase sales by pleasing crowds but unable to expand market share. In markets where brands are quite dissimilar, sales promotions expand market shares but have to count on particular customers. The sales promotions present variety of tactics during the late 20th century [24]. The popularity lies in such factors as more sophisticated techniques and greater pressure to survive market [25].

Concisely, being consistently warned by the result (output) and a quick reaction to the malignant signs ensure a healthy increase of business. Namely, a rational evaluation of result (output) optimizes the implementation of strategy (throughput).

\section{About Output (Metal): Is it possible for marketing turns negative influences of the results into positive ones?}

According to Wu Hsing theory, Earth enlivens Metal. In other words, earth conditions formation of rocks where metal come from. Taking it into marketing, the favorable (unfavorable) environment conditions the existence of a promising (poor) output.

Critics have raised concerns about marketing by saying that it increases prices by encouraging excessive markups. 
Companies tactically convince consumers to pay more for some intangible and unpractical qualities. For instance, a diamond from Cartier costs ten times more than its physical value. However, the assumption that customers pay extra for the cost of promotion and distribution is not reasonable. The reason that why customers are will to pay more for luxury products lies in three elements: 1 . Public relation cost are higher than that of industry norms; 2. Symbolic value bears more benefits than the mere functional one. By creating a symbol of prestige, luxury's symbolic significance justifies the price. In addition, brands may symbolize not only prestige but also quality and functionality, which gives consumers greater confidence when they purchase a branded product [26]. Besides, a few marketers have been accused of using deceptive practices, such as misleading promotional activities or high-pressure selling. These deceptive practices have given rise to legislative and administrative remedies [27].

Besides, some marketing activities are accused of encouraging excessive interest in material possessions, inducing negative necessities and inviting the purchase of the wants instead of needs.

Marketing are accused for its over-manipulation of selfish interests and its deliberate ignorance of social and public concern. For example, some big companies show their snobbery interests in legislation, media, and individual behavior so as to overwhelm such policies as environment, health and education, which may be negative to their profit making business.

\section{E. About feedback (Water): is it possible for marketing consistently winning a positive image when it is in nature a way of making profit?}

According to Wu Hsing theory, Metal enriches Water (as in water with minerals is more beneficial to the body than pure water). In other words, Metal endows Water with better qualities. Taking it into marketing, thank to a positive output, companies wins a favorable feedback.

Unlike snobbery advertising and sales promotion, the modes less commercialized and more publicized of communication characterize public relations. Its primary purpose is to disseminate information and opinion to groups and individuals who have an actual or potential impact on a company's ability to achieve its objectives. In addition, public relations specialists are responsible for monitoring these individuals and groups and for maintaining good relationships with them.One of their missions is to work with news and information media to ensure appropriate coverage of the company's activities and products. Another mission is to deal with crisis by coping with the situations that negatively impact the company's ability to achieve its goals. For example, when it was discovered that some bottles of Perrier sparkling water might have been tainted by a harmful chemical, Source Perrier, SA's public relations team, had to ensure that the general consuming public did not thereafter automatically associate Perrier with tainted water. Other public relations activities include lobbying, advising management about public issues, and planning community events.
Public relations do not always seek to impact sales or profitability directly and it is sometimes seen as serving a function that is separate from marketing. However, some companies recognize that public relations can work in conjunction with other marketing activities to facilitate the exchange process directly and indirectly.

\section{CONCLUSION}

$\mathrm{Wu}$ Hsing, lending substance to the characteristically Chinese belief in a cyclical theory of becoming and dissolution and interdependence between the world of nature and human events, makes up all aspects and phenomena of life and explains change and persistence in cosmos philosophically. The significance of the attempt lies in an assumption that if the ancient wisdom endows us a new perspective to implement modern business strategies. The more the assumption being verified, culturally the brighter the ancient wisdom's light shed on human culture, and technically the more efficient the marketing implementation is.

\section{ACKNOWLEDGE}

My deepest gratitude goes to those who supported me in so many ways and appreciation to my family.

\section{REFERENCE}

[1] D.A. Aaker and A.L. Biel, "Brand Equity \& Advertising," Psychology Press, 1993, pp. 32-33.

[2] D.A. Aaker and G.S. Day, "Consumerism: Search for Consumer Interest," 4th ed., Free Press, 1982, pp. 3-6.

[3] D.A. Aaker, "Managing Brand Equity," Free Press, 1991, pp. 11-15.

[4] D.A. Aaker, "Managing Services: Marketing, Operations, and Human Resources," 2nd ed., Free Press, 1991, pp. 126-127.

[5] D.A. Aaker, "Strategic Market Management," Wiley, 1991, pp. 67-69.

[6] D.E. Schultz, S.I. Tannenbaum, and R.F. Lauterborn, "Integrated Marketing Communications," McGraw-Hill College, 1992, pp. 111-113.

[7] G.A. Churchill, "Marketing Research: Methodological Foundations," 5th ed., South-Western, Div of Thomson Learning, 1991, pp. 214-215.

[8] G.A. Churchill, N.M. Ford, and O.C. Walker, "Sales Force Management," 4th ed., McGraw-Hill College, 1993, pp. 312-313.

[9] G.L. Urban and J. Hauser, "Design and Marketing of New Products," 2nd ed., Englewood Cliffs, New Jersey: Prentice Hall, 1993, pp. 21-22.

[10] J. Trout and A.L. Reis, "Positioning: The Battle for Your Mind," Warner books, 1986, pp. 191-192.

[11] J. Lyons, "Guts: Advertising from the Inside Out," Free Press, 1987, pp. $12-13$.

[12] L.W. Stern and A.I. El-Ansary, "Marketing Channels," 4th ed., Englewood Cliffs, New Jersey: Prentice Hall, 1992, pp. 17-20.

[13] M.L. Roberts and P.D. Berger, "Direct Marketing Management," Englewood Cliffs, New Jersey: Prentice Hall, 1989, pp. 221-229.

[14] M.D. Hutt and T.W. Speh, "Business Marketing Management: A Strategic View of Industrial and Organizational Markets," Dryden Press, 1992, pp. 170-181.

[15] M.R. Czinkota and I.A. Ronkainen, "International Marketing," 3rd ed., South-Western, Division of Thomson Learning, 1993, pp. 78-82.

[16] M.R. Solomon, “Consumer Behavior,” Dryden Press, 1994, pp. 39-42.

[17] Philip Kotler and Alan R, Andreasen, "Strategic Marketing for Nonprofit Organizations," 4th ed., Englewood Cliffs, New Jersey: Prentice Hall, 1991, pp. 211-212. 
[18] P. Kotler and E. Roberto, "Social Marketing: Strategies for Changing Public Behavior," Free Press, 1989, pp. 2542-245.

[19] P. Kotler and R.N. Clarke, "Marketing for Healthcare Organizations," Jossey-Bass, 1986, pp. 341-345.

[20] P. Kotler, D.H. Heider, and I. Rein, "Marketing Places: Attracting Investment," Industry, and Tourism to Cities, States, and Nations, Free Press, 1993, pp. 541-544.

[21] R. McKenna, "Relationship Marketing:Successful Strategies for the Age of the Customer Basic Books," 1991, pp. 121-123.

[22] R. Bartels, "History of Marketing Thought," 3rd ed., Free Press, 1988, pp. $37-41$
[23] S. Rapp and T.L. Collins, "Beyond Maximarketing," McGraw-Hill Companies, 1994, pp. 102-107.

[24] S.P. Schnars, "Marketing Strategy: A Customer-Driven Approach," Free Press, 1991, pp. 101-104.

[25] T. Levitt, "The Marketing Imagination, new, expanded," Free Press, 1986, pp. 49-51.

[26] T.T. Nagle and R.K. Holden, "The Strategy and Tactics of Pricing," 2nd ed., Englewood Cliffs, NJ: Prentice Hall, 1994, pp. 66-68.

[27] W. Aldersonkk, "Dynamic Marketing Behavior: A Functionalist Theory of Marketing," Homewood, IL: Richard D, Irwin, Inc, 1965, pp. 7-11. 